\title{
South Fork lowa River Watershed Selected for a National Water-Quality Study
}

The U.S. Geological Survey (USGS) is studying seven watersheds across the Nation to better understand how natural factors and agricultural management practices (AMPs) affect the transport of water and chemicals. Natural factors include climate and landscape (soil type, topography, geology), and AMPs include practices related to tillage, irrigation, and chemical application. The study approach is similar in each watershed so that we can compare and contrast the results and more accurately predict conditions in other agricultural settings.

\section{Study objectives}

- Understand the links between the sources of water and agricultural chemicals (nutrients and pesticides) and their behavior and transport through the environment

- Predict the behavior and transport of water and agricultural chemicals in other agricultural areas not being studied

- Evaluate what the study results mean for management of water and water quality in a variety of agricultural settings

\section{We appreciate your help}

We are working with local growers and land owners to gain access to study sites. We also need information about the watershed and about current as well as historical agricultural management practices-past practices also affect concentrations of agricultural chemicals in ground and surface water.

We will report the findings of the study in public meetings and in publications. These findings will provide information that will be useful for improving agricultural management locally and nationally, and will guide future studies in other watersheds.

\section{Why study the South Fork lowa River watershed?}

The South Fork Iowa River and the other watersheds represent nationally important agricultural settings (chemical use, crops, and AMPs) and natural settings (climate, soils, topography, and geology). South Fork Iowa River, which is part of the Iowa River watershed, is representative of corn and soybean row cropping in the Midwest.

Other features of the watershed that are relevant to this study:

- Use of agricultural chemicals: Commonly used chemicals include herbicides such as atrazine, acetochlor, metolachlor, and glyphosate; and fertilizers, both manure and chemical.

- Distinct natural setting: Low relief topography with common depressions that formerly formed ponds and wetlands and that are now drained by an extensive network of drainage tiles and ditches.

- Variety of agricultural management practices: AMPs include both tillage and no-tillage of fields used for corn and soybean production; production of large numbers of hogs in concentrated animal feeding facilities; small grassy riparian buffer zones commonly used to reduce overland runoff.

- Water-quality issues: Herbicides and nutrients have been frequently detected in Iowa surface and ground water, including in drinking-water wells (findings of USGS studies since the 1990s).

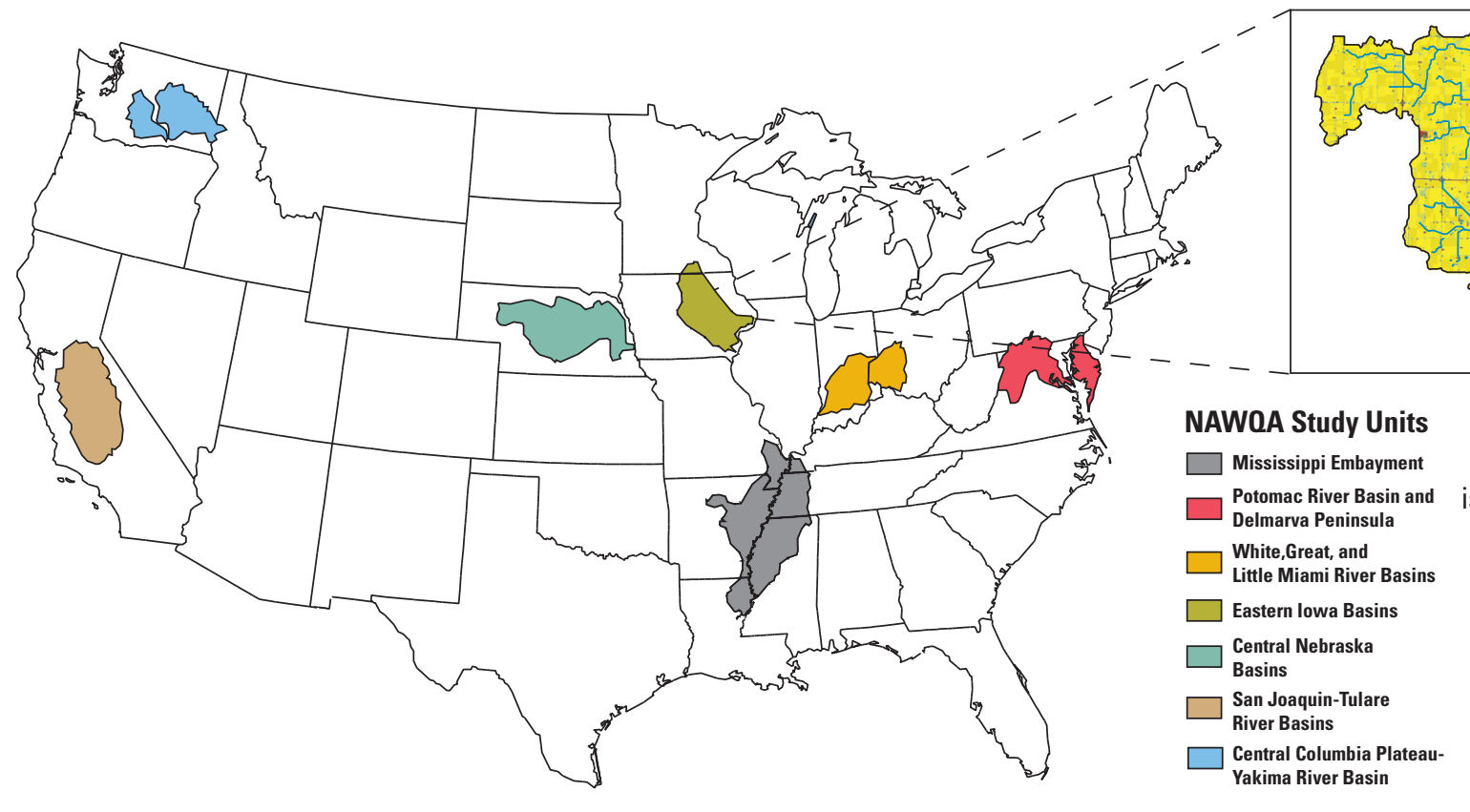

The South Fork lowa River watershed in central lowa is one of seven watersheds selected by the USGS National Water-Quality Assessment (NAWQA) Program for a special study of agricultural chemicals and water quality. 
At a typical study site, several methods are used to collect water and chemical samples from the air, soil, surface water, and ground water.

After being applied to the land surface, agricultural chemicals can move upward into the atmosphere, downward through the soil to shallow ground water and underlying aquifers, eventually discharge to streams or run off across the land into streams, and move downstream to reservoirs and coastal waters. This process can take days, weeks, or even decades if water moves underground through the ground-water system.

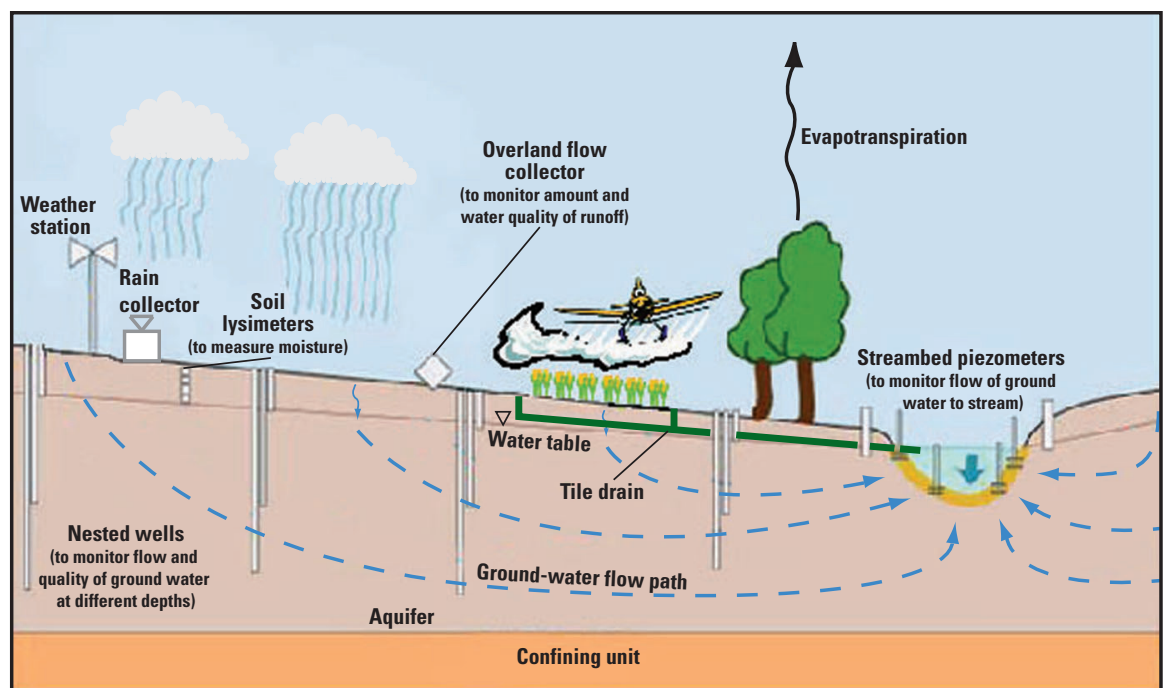

\section{Data Collection in the South Fork lowa River Watershed, 2007-2008}

\section{What kind of data}

\section{Meteorological data, including rainfall,} wind speed, solar radiation, and air temperature. Soil temperature and moisture

Amount of streamflow at South Fork Iowa River near New Providence, IA, gaging station

Quality of stream water, runoff water, and rain water ${ }^{1}$

Ground-water levels in wells

Quality of ground water, soil water, and shallow water in and around streambed/ riparian zone ${ }^{1}$

Quality of sediment in streambed and soils in agricultural fields ${ }^{1}$

\section{Why the data are collected}

To determine amount of precipitation, how much water from land surface reaches the water table, and how much is lost to evapotranspiration

To interpret water-quality data correctly (the amount of water in streams affects chemical concentrations)

To quantify the transport and behavior of natural and agricultural chemicals

To determine direction of ground-water flow, which affects transport of chemicals

To quantify the transport and behavior of natural and agricultural chemicals

To quantify the storage, behavior, and transport of water and chemicals in the soils and sediment
Continuously since 1996 at South Fork Iowa River (real-time data available at $h t t p: / / w a t e r d a t a . u s g s$. gov/ia/nwis/uv?05451210).

Several times a year $(>14$ samples) for 2 years, with intensive sampling during application seasons

At least quarterly in some wells, continuously in others for at least 1 year

At least quarterly for 1 year

At least once during study

${ }^{1}$ In this study, water-quality and sediment-quality data include concentrations of nutrients (nitrogen and phosphorous), pesticides and pesticide breakdown products, and natural constituents and properties, including major ions (calcium, magnesium, chloride, etc.), organic carbon, dissolved oxygen, and temperature.

\section{We would like to thank}

U.S. Department of Agriculture Agricultural Research Service Natural Resources Conservation Service

lowa Department of Natural Resources lowa Geological Survey

lowa State University

South Fork Watershed Alliance

\section{For more information}

Stephen Kalkhoff, Lead Scientist, South Fork lowa River study

(319) 358-3611, sjkalkho@usgs.gov

Paul Capel, Team Leader, National study

(612)625-3082, capel@usgs.gov

NAWQA Program http://water.usgs.gov/nawqa

\section{Publication}

Kalkhoff, S.J., Barnes, K.K., Becher, K.D., Savoca, M.E., Schnoebelen, D.J., Sadorf, E.M., Porter, S.D., and Sullivan, D.J., 2000, Water Quality in the Eastern lowa Basins, lowa and Minnesota, 1996-98, U.S. Geological Survey Circular 1210, 37 p. Available online at $h t t p: / / w a t e r$. usgs.gov/pubs/circ/circ1210/ 